JEL: O47, O12, M21

\author{
Viktoriia Kyfyak, Olena Vinnychuk, Liudmyla Sybyrka, Liubov Vodianka
}

Yuriy Fedkovych Chernivtsi National University

Ukraine

\title{
MEASURING ENTREPRENEURSHIP DETERMINANTS: EMPIRICAL ANALYSIS
}

Purpose. The aim of this article is to assess the main determinants that affect entrepreneurial activity, and also the mechanism of its regulation in five countries (Ukraine, Romania, Lithuania, Poland, Germany) during the period from 2007 to 2018. According to the purpose of the article it was empirically tested a number of hypotheses.

Methodology / approach. The canonical correlation method is considered as a basic method for maximum correlations between groups of variables. The group of performance indicators includes: GDP per capita, the volume of output at market prices, Global Competitiveness Index as indicators that most completely reflect the results and efficiency of entrepreneurial activity. The group of factor variables includes entrepreneurial activity determinants, which to some extent affect the change of these entrepreneurial efficiency indicators. The advantages of the proposed method is possibility to analyze the multiple relationships between business results and the determinants that determine it.

Results. The article examines a related area of the economy, namely entrepreneurship, which is largely related to agriculture. The article gradually reveals scientific approaches to identifying the determinants of entrepreneurial activity, followed by the methodology of the conducted research, analysis of results and substantiation of hypotheses. According to the aims of the article, the authors have got the following results: 1. To analyze the entrepreneurial environment, a systematic approach must be applied whereby all the determinants of the entrepreneurial environment are interrelated and influence one another. 2. The canonical correlation method allowed to determine the system of entrepreneurial activity determinants and to confirm the statement that each country has its own system of determinants. It is justified by the heterogeneity of the studied data sample, i.e. the presence of a large difference between the numerical values of indicators for selected countries. 3. The human development determinant is the key to business development in the country. Such conclusions are made on the basis of the determinants system analysis in Germany, where indicators of business efficiency are the highest.

Originality / scientific novelty. The article proposes a method of assessing the determinants of entrepreneurial activity through the use of the canonical correlation method. This method allows us to investigate the relationship between two sets of variables and is a generalized version of pairwise correlation, as opposed to factor analysis, which is used to establish relationships within one set of variables.

Practical value / implications. Presented study aims to extend the empirical knowledge on the measurement of entrepreneurship at the country level and its determinants. In assessing the determinants of the entrepreneurial environment, the main causes that lead to incomplete utilization of entrepreneurial potential remain unaccounted for. Particularly practical meaning may have a thorough analysis of the determinants of entrepreneurial activity in different countries. Modern European integration aspirations of Ukraine should be provided with real socioeconomic transformations in which the development of entrepreneurial activity is key. The beginning of an effective process of forming an efficient strategic approach to creating a favourable entrepreneurial 


\section{Agricultural and Resource Economics: International Scientific E-Journal}

http://are-journal.com

environment for every country is to study the existing experience of other countries. For Ukraine, in particular, this is the experience of the EU countries.

Key words: entrepreneurship determinants, canonical correlation analysis, systematic approach, correlation analysis.

Introduction and review of literature. The formation of efficient mechanisms of economic development should be based on a clear understanding of the interconnections and interdependence of the system of functioning of economic entities. For this very reason most modern theories of transformation are based on a systematic approach to change. Thus, the core of the national economy is entrepreneurship, the development of which is a consistent component of all other processes of economics. In this context, the connection between economic growth and entrepreneurship that such scholars as J. E. Prieger, C. Bampoky, L. R. Blanco, A. Liu (2016), D. Urbano, S. Aparicio (2016), P. García-Villaverde, J. RodrigoAlarcón, G. Parra-Requena, M. J. Ruiz-Ortega (2018) have proved in their works is clearly evident. According to systems theory, there is also a feedback, according to which the relations that have developed in the national economy determine the level of entrepreneurship development.

Entrepreneurship as a driving force of the national economy is studied by many scientists at different levels (micro-, meso- and macro-) and using different methods (empirical description, development of strategic directions, factor analysis, study of determinants of entrepreneurial activity between different temporal and spatial objects of research etc.). Therefore, there is no doubt that systematic approach to the study of entrepreneurship needs to be used as a basic one.

According to the systematic approach, entrepreneurial activity relies on the system of determinants that define its development (Aparicio et al., 2015; Fuentelsaz et al., 2015; Boudreaux et al., 2019). Determinants of entrepreneurship are seen as a system of conditions that hierarchically builds the effect of institutions and organizations of the economic mechanism to shape the entrepreneurial environment. An empirical method of studying such determinants was considered by O. Dvoulety (2018). At the national level, a methodological approach to the study of determinants was proposed L. Jiangyong and T. Zhigang (2010).

Therefore, in the current context, it is important to investigate not the state but the dynamics of changes in economic processes in interconnection and interaction and their impact on entrepreneurial activity. The most popular methodologies are those based on systematic approach using economic and mathematical modeling methods. One such methodical tool is the canonical correlation method.

The method of canonical correlation analysis was first published by the American economist H. Hotelling (1936). The application of this type of analysis to the determinants of entrepreneurial activity was made in the paper of R. Volchek (2012). According to C. Marcotte (2013), Z. Acs et al. (2014), J. Iversen et al. (2010) and E. Congregado (2008), assessment of entrepreneurial activity at country and interstate levels is still an underrepresented area of research. Therefore, the research, 


\section{Agricultural and Resource Economics: International Scientific E-Journal}

http://are-journal.com

which built a system of determinants of entrepreneurial activity is relevant and actual.

Presented study aims to extend the empirical knowledge on the measurement of entrepreneurial determinants at the country level.

The study of the business environment determinants and the main reasons that lead to incomplete use of entrepreneurial potential is a necessary condition for economic growth and the formation of a favorable environment for entrepreneurial development. In the conditions of globalization and economic systems integration the implementation of approaches of the European countries to formation of entrepreneurial development determinants is especially important for Ukraine. Under conditions of effectiveness, such factors should become a benchmark for the strategic priorities determining of the economic relations development in Ukraine. Therefore, a sound analysis method of foreign experience is a key factor in shaping the entrepreneurial activity determinants in the country.

The purpose of the article is offering a well-founded approach to the formation of a methodology for estimating the determinants of entrepreneurial activity; to empirically validate these relations and the hypothesis that different countries can choose a system of determinants that can be driven in the desired direction to achieve an increase in the entrepreneurial activity indicators (to empirically support a hypothesis, that entrepreneurial activity is influenced by a system of determinants that determine the results of the national economy).

Results and discussion. Summarizing all of the above, we offer the following sequence of assessing the impact of determinants on entrepreneurship.

1. Develop a methodologic approach for assessing the determinants of entrepreneurial activity.

2. Select the most important determinants that most accurately describe entrepreneurial activity among a large number of indicators. In our study, there are two groups:

a) entrepreneurship performance indicators (Gross Domestic Product at actual prices per capita; Volume of output at market prices; Global Competitiveness Index);

b) factor indicators of entrepreneurial activity (total amount of innovation expenditures in the country (X1); share capital per capita (X2); export (X3); import (X4); capital investment (X5); number of employed population (X6); number of unemployed population (X7); average wage (X8); volume of sold products, goods, services by enterprises (X9); population incomes (X10); disposable income per capita (X11); the number of economically active population (X12); the need of employers for workers (X13); real disposable income of the population (X14); expenditures for the personnel of the enterprise (X15)).

3. To form a sample of countries for analysis (Ukraine, Poland, Lithuania, Romania, Germany) and explore the different features of the factors of entrepreneurial development in them.

In accordance the purpose of the article and the sequence of assessing the impact of determinants on entrepreneurship, the authors propose the following hypotheses:

Hypothesis 1. To analyze the entrepreneurial environment, a systematic 
approach must be applied whereby all the determinants of the entrepreneurial environment are interrelated and influence one another.

Hypothesis 2. The canonical correlation method makes possible to determine system factors of entrepreneurial activity and confirms the fact that each country has its own determinants system.

Hypothesis 3. The results of entrepreneurial activity that meet the principles of sustainable development are the most effective, in particular the determinant of human development. The level of human resources development reflects the state of economic and political relations, which determine the competitive position of entrepreneurship and its efficiency.

Measuring determinants of entrepreneurial activity: research methodology. In order to determine the effective mechanisms of development of one of the main driving forces of the economy - entrepreneurship, it is necessary to determine the objective regular relationship and interdependence of external conditions of its functioning as a complex dynamic system.

According to D. Urbano (2016), the determinants of entrepreneurial activity reflect both internal and external causal relationships between the genesis and evolution of the entrepreneurial phenomenon.

In practice, defining the main determinants of entrepreneurial activity is important in the aspect of forming the research methodology, and, most importantly, in understanding the essence of entrepreneurship, in order to form effective mechanisms for its development and taking into account competitive advantages. Determinant structuring can serve as a basis for a country's entrepreneurship development program and for an individual business entity.

Thus, the determinant of entrepreneurial activity is a complex concept that characterizes the factor of the entrepreneurial environment, which, on the one hand, defines the form and type of relations that have developed in economic activity, and on the other hand, is their component.

Identification and monitoring of the determinants of entrepreneurial activity provide the analysis tools, but, as a rule, it is carried out using the apparatus of economic and mathematical modelling. Generally, regression analysis is used to construct multifactorial models of determinant influence on entrepreneurial activity. The results of these methods of analysis reflect the development level of the country's economic relations and the influence of factors on an indicator that reflects the purpose of the activity. However, it is important for the formation of effective mechanisms for the development of the national economy to assess the impact of entrepreneurial activity on the set of indicators that reflect the quantitative and qualitative economic results. The canonical correlation method is a tool for assessment the relationships between quantitative and qualitative indicators of entrepreneurial results and the system of its determinants.

Canonical correlation is the spread of pairwise correlation to the case when there are several performance indicators $\mathrm{Y}$ and several factors $\mathrm{X}$. This does not require the absence of correlation both in the group of performance indicators and in the group of 


\section{Agricultural and Resource Economics: International Scientific E-Journal http://are-journal.com}

factors. The algorithm for the canonical correlations method calculating is built in such a way that the initial variables are replaced by their linear independent combinations. The main purpose of this method is to find the maximum correlations between groups of variables. In addition, the canonical correlations method makes it possible to reduce the amount of initial data by eliminating low-impact factors. The main difference between the canonical correlations analysis and the corresponding regression model is that it takes into account the multiple relationships between business results and the factors that determine it.

Sample selection. Determinants, formed on the basis of analysis of a considerable number of indicators and indices, reflecting various aspects of entrepreneurial activity of European countries are considered in the article.

The beginning of forming process is building an effective strategic approach to creating a favorable environment for entrepreneurial development in any country is a study of existing experience in this area of the world, for Ukraine - it is, in particular, the experience of EU countries.

Germany was chosen as the benchmark in which the determinants of entrepreneurship provide the highest impact. Romania, Poland, and Lithuania have been chosen as neighboring countries that have had the same start, but have achieved different positions, whose experience is useful to us, and with whom we have close ties in doing business.

Therefore, the analysis was performed by comparing different pairs of correlation relationships. The analysis identifies two main groups of indicators: performance (reflecting entrepreneurial performance) and factor (assessing resources and indicators that affect entrepreneurial performance). The relevant indicators reflect the quantitative and qualitative aspect of a particular determinant of entrepreneurial activity. That is, we have determined to what extent a determinant defines the results of entrepreneurial activity.

For analysis and identification of factors of entrepreneurial activity statistics of Ukraine, Romania, Lithuania, Poland, Germany from 2007 to 2018 were selected. The data set from these countries used in this study consists of performance indicators and determinants of entrepreneurial activity covering the period between 2007 and 2018. Data are obtained from Eurostat (Eurostat, 2019).

It is worth characterizing the sample that is formed for the study - the selected outputs of GDP per capita and the output produced reflect the quantitative results of entrepreneurial activity in the countries, while the Global Competitiveness Index reflects their quality side. Each indicator characterizes one or the other aspect of a particular determinant of entrepreneurial activity. At the beginning of the study, the following indicators were analysed: Global Innovation Index (2019), Index of Economic Freedom (2019), Ease of doing business Index (2019), Human Development Index (2019), which did not show a significant correlation with indicators of entrepreneurial efficiency and to some extent are part of the selected indicators.

Dependent variables. The indicators we have selected are those that most fully 
reflect the results of entrepreneurial activity.

This is the gross domestic product at actual prices per person $(Y 1)$, the volume of output at market prices (Y2) and the Global Competitiveness Index (Y2).

The dynamics of these indicators are shown at the Fig. 1 (GDP), Fig. 2 (volume of output at market prices), Fig. 3 (Global Competitiveness Index).

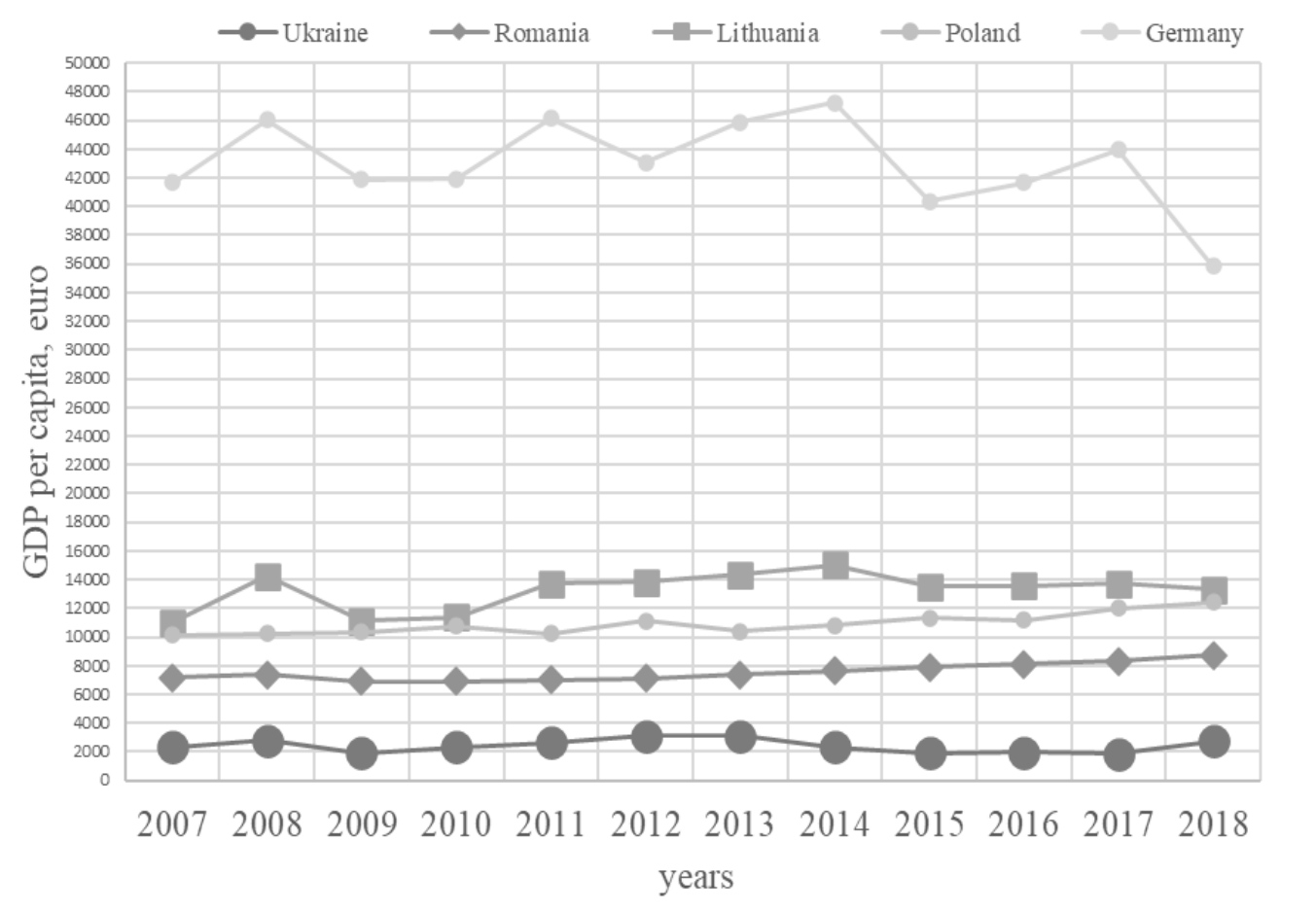

Fig. 1. GDP per capita, euro, 2007-2018

Source: data from Eurostat (2019).

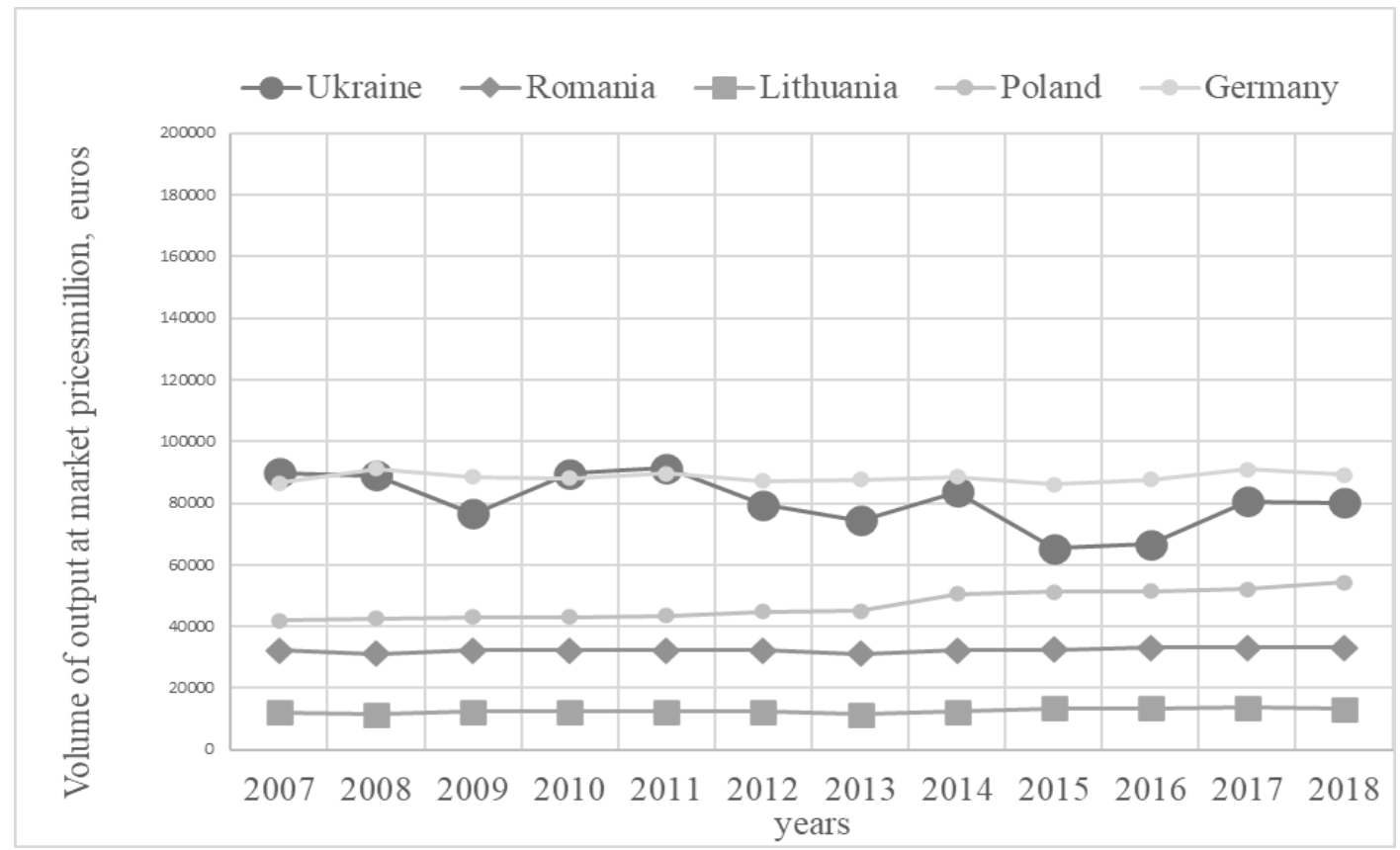

Fig. 2. The volume of output at market prices, million euros, 2007-2018 Source: data from Eurostat (2019). 


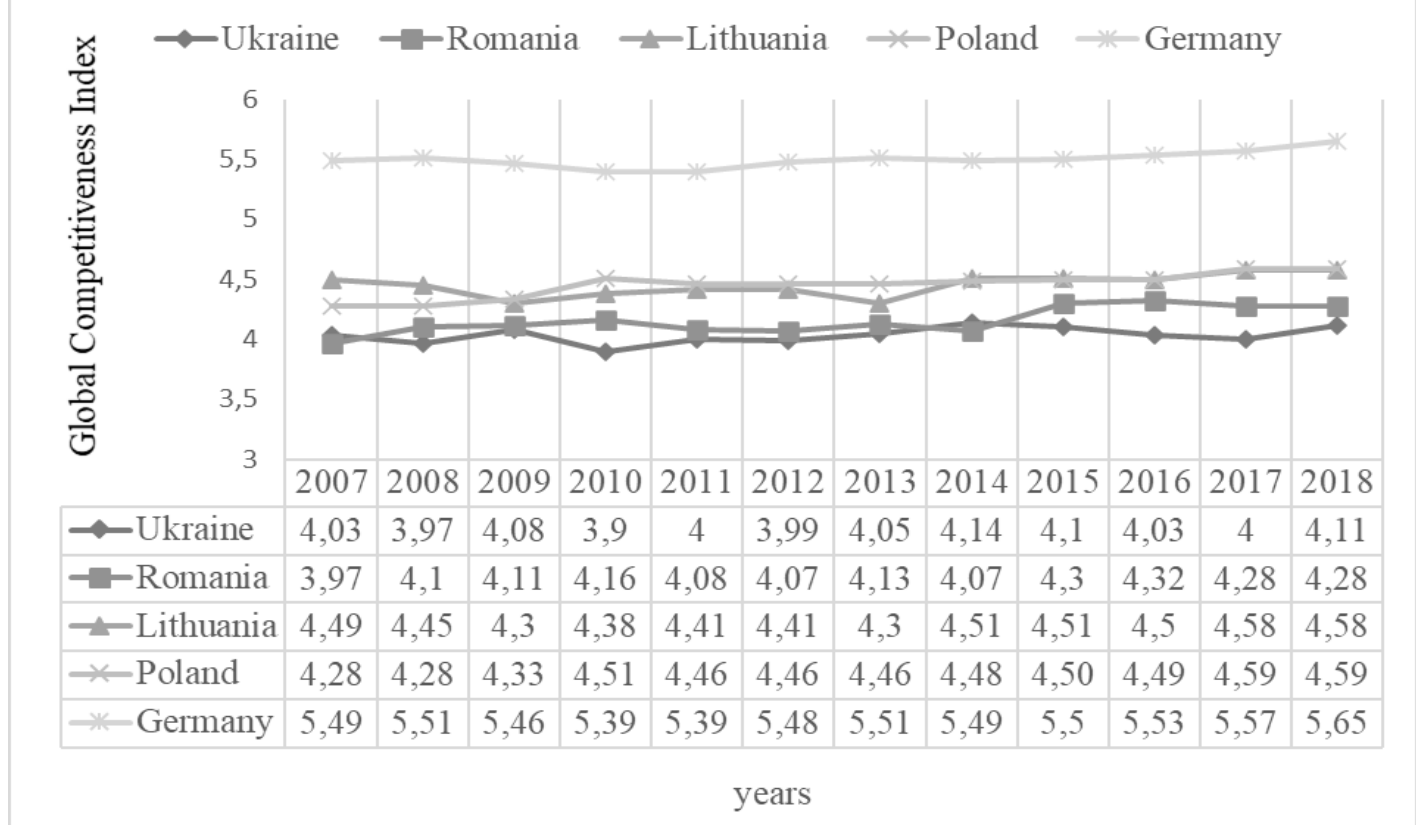

Fig. 3. Global Competitiveness Index, 2007-2018

Source: Global Competitiveness Report (2019).

According to Fig. 1, the highest level of GDP per capita is in Germany, with fluctuations in the index at different times also being the highest in Germany, which is well-suited to systems development theory, according to which stronger fluctuations of indicators lead to a higher level of development of the system. That is, entrepreneurship is directly related to the ability to function in the face of constant unforeseen change in the material factor influencing it.

In Fig. 2, we note that the level of output was calculated according to the Eurostat methodology (in Ukraine the method of calculating this indicator is somewhat different). The calculations of this indicator are aligned to the Eurostat methodology by the authors themselves. We are observing that in 2014 there was a sharp decline in the volume of manufactured products in Ukraine, which is connected with the emergence of the military conflict in the East of the country and annexation of Crimea.

According to the Global Competitiveness Index we can note the growth of positions of Germany, Poland and Romania. Since 2016, we have seen a decline in the Lithuanian index.

Descriptive statistics for the time series used in the analysis are summarized in Table 1.

According to Table 1, there is a significant variation of indicators, which, for one part, characterizes the level of stability and uncertainty of the functioning of the entrepreneurial environment, and the potential for the other part.

Thus, the biggest variation in GDP is in Germany and the least is in Ukraine. The biggest volume of production is in Ukraine, and the slightest fluctuations in these indicators are in Romania and Lithuania.

The average value of the Global Competitiveness Index is the highest in Germany, with a high maximum and minimum value. The lowest index is in Ukraine. 
Therefore, all performance indicators are the highest (among the surveyed countries) in Germany. For this reason, we consider this country as an example of an entrepreneurial environment with the most effective determinant system.

Table 1

Descriptive Statistics (Dependent variables)

\begin{tabular}{|c|l|c|c|c|c|}
\hline Countries & \multicolumn{1}{|c|}{ Indicators } & Mean & Min & Max & Std. Dev \\
\hline \multirow{4}{*}{ Ukraine } & GDP per capita, euros & 2426,53 & 1891,10 & 3116,51 & 458,29 \\
\cline { 2 - 6 } & Output, million euros & 79547,94 & 65383,39 & 89941,92 & 8074,64 \\
\cline { 2 - 6 } & IGC & 4,03 & 3,90 & 4,14 & 0,07 \\
\hline \multirow{4}{*}{ Lomania } & GDP per capita, euros & 7552,53 & 6914,60 & 8740,00 & 601,83 \\
\cline { 2 - 6 } & Output, million euros & 32242,11 & 31111,40 & 33153,60 & 684,28 \\
\cline { 2 - 6 } & IGC & 4,16 & 3,97 & 4,32 & 0,11 \\
\hline \multirow{4}{*}{ Poland } & GDP per capita, euros & 13234,84 & 11024,30 & 15012,10 & 1325,15 \\
\cline { 2 - 6 } & Output, million euros & 12560,90 & 11386,40 & 13589,70 & 758,28 \\
\cline { 2 - 6 } & IGC & 4,45 & 4,30 & 4,58 & 0,09 \\
\hline & GDP per capita, euros & 10909,14 & 10114,80 & 12430,00 & 732,23 \\
\cline { 2 - 6 } & Output, million euros & 46942,27 & 41867,20 & 54222,71 & 4546,02 \\
\cline { 2 - 6 } & IGC & 4,45 & 4,28 & 4,59 & 0,10 \\
\hline \multirow{3}{*}{ Germany } & GDP per capita, euros & 42969,42 & 35860,00 & 47219,00 & 3161,89 \\
\cline { 2 - 6 } & Output, million euros & 88419,15 & 86114,20 & 91237,10 & 1599,83 \\
\cline { 2 - 6 } & IGC & 5,50 & 5,39 & 5,65 & 0,07 \\
\hline
\end{tabular}

Source: research results - the base for calculations are data from Eurostat (2019).

Independent variables. Fifteen factors were selected as the factors $(X)$ influencing the change in the specified criteria for entrepreneurial activity $(Y)$ (X1$\mathrm{X} 15)$.

The average values of all selected factors for each country studied is shown in Table 2.

Table 2

Mean (Independent variables)

\begin{tabular}{|c|c|c|c|c|c|}
\hline Factors & Ukraine & Romania & Lithuania & Poland & Germany \\
\hline X1 & 1745,77 & 8962,79 & 141,03 & 34454,63 & 40910,99 \\
\hline X2 & 854,75 & 1476,67 & 1954,11 & 4619,66 & 12899,21 \\
\hline X3 & 52309,72 & 54752,15 & 24867,84 & 186563,43 & 1068160,00 \\
\hline X4 & 58730,17 & 61376,81 & 25298,49 & 179935,04 & 875701,27 \\
\hline X5 & 38314,98 & 39161,63 & 129857,58 & 62198,24 & 125884,08 \\
\hline X6 & 18881,00 & 8446,17 & 1306,58 & 15591,42 & 39117,42 \\
\hline X7 & 1676,75 & 584,17 & 152,58 & 1365,92 & 2343,17 \\
\hline X8 & 228,30 & 519,08 & 567,01 & 912,63 & 3079,87 \\
\hline X9 & 303386,60 & 115,38 & 151,87 & 13932,64 & 43945,93 \\
\hline X10 & 94784,53 & 1995,94 & 2568,69 & 2370,07 & 2587,88 \\
\hline X11 & 4091,48 & 12726,83 & 10557,25 & 8892,76 & 14789,48 \\
\hline X12 & 20507,93 & 8987,92 & 1457,33 & 17061,58 & 41201,25 \\
\hline X13 & 62,29 & 84,06 & 23,47 & 299,70 & 307,16 \\
\hline X14 & 181,04 & 104,13 & 103,58 & 105,08 & 104,57 \\
\hline X15 & 23818,15 & 17648,33 & 13300,47 & 43226,70 & 86825,93 \\
\hline
\end{tabular}

Source: own calculations. 
An analysis of the dynamics of entrepreneurial activity indicators to determine the direction of causal relationships leads to the conclusion that the variables of the first group, which characterize the criteria for change of business activity, are effective, dependent and defined as $Y 1, Y 2, Y 3$. The indicators of the second group are factor, unchanged and are defined as $X 1, X 2, \ldots X 15$.

The mathematical problem of canonical correlations method in our case is to find such normalized linear combinations $U=\sum_{i=1}^{3} \alpha_{i} y_{i}$ and $V=\sum_{j=1}^{15} \beta_{j} x_{j}$, to correlate between $U$ and $V$ to be maximum. The relationship between the canonical quantities is measured using the canonical correlation coefficient $\mathrm{R}$.

In the course of the research an attempt was made to solve the following main tasks: to evaluate the closeness of the canonical correlation between the first and second groups of traits, to check the statistical reliability; to identify and analyze the indicators that influence the main criteria for change of entrepreneurial activity, which will become the basis for creating a business development program in the country.

Empirical analysis. Using the canonical correlation method, we test the postulates of a systematic approach whereby all determinants of the business environment are interrelated and influence one another.

Using the Canonical Analysis module of the software product Statistica 12, we perform a canonical correlation analysis of two sets of variables $\mathrm{Y}$ and $\mathrm{X}$.

The results of the analysis are shown in Fig. 4.

\begin{tabular}{|c|c|c|c|c|}
\hline \multirow{2}{*}{\multicolumn{2}{|c|}{$\mathrm{N}=60$}} & \multicolumn{3}{|c|}{$\begin{array}{l}\text { Canonical Analysis Summary (all countries) } \\
\text { Canonical R: }, 99371 \\
\text { Chi?(45) }=359,20 p=0,0000\end{array}$} \\
\hline & & $\begin{array}{c}\text { Left } \\
\text { Set }\end{array}$ & $\begin{array}{l}\text { Right } \\
\text { Set }\end{array}$ & \\
\hline \multicolumn{2}{|c|}{ No. of variables } & 3 & 15 & \\
\hline \multicolumn{2}{|c|}{ Variance extracted } & $100,000 \%$ & $69,4202 \%$ & \\
\hline \multicolumn{2}{|c|}{ Total redundancy } & $94,0318 \%$ & $65,0635 \%$ & \\
\hline \multirow[t]{15}{*}{ Variables: } & 1 & $\begin{array}{l}\mathrm{Y}^{1} \\
\end{array}$ & X1 & \\
\hline & 2 & Y2 & X2 & \\
\hline & 3 & $\mathrm{Y3}_{3}$ & X3 & \\
\hline & 4 & & $\mathrm{X} 4$ & \\
\hline & 5 & & $\mathrm{X} 5$ & \\
\hline & 6 & & $\mathrm{X} 6$ & \\
\hline & 7 & & $\mathrm{X} 7$ & \\
\hline & 8 & & $\mathrm{X} 8$ & \\
\hline & 9 & & X9 & \\
\hline & 10 & & $\mathrm{X} 10$ & \\
\hline & 11 & & X11 & \\
\hline & 12 & & X12 & \\
\hline & 13 & & $\mathrm{X} 13$ & \\
\hline & 14 & & X14 & \\
\hline & 15 & & $\mathrm{X} 15$ & \\
\hline
\end{tabular}

Fig. 4. Canonical analysis summary for the five countries, 2007-2018

Source: own calculations depicted in Statistica 12. 


\section{Agricultural and Resource Economics: International Scientific E-Journal}

http://are-journal.com

Analysis of the results in Fig. 4 showed that, as a result of the canonical analysis, the total redundancy for the variables of the first small group (Y1-Y3) is $94,0 \%$, and the total redundancy for the variables of the second large group (X1$\mathrm{X} 15)$ is $65,1 \%$. This means that $94,0 \%$ of the variation in the main determinants of entrepreneurial activity in the countries studied is determined by a change in fifteen factors $(\mathrm{X} 1-\mathrm{X} 15)$. At the same time, the main determinants of entrepreneurial activity describe $65,1 \%$ of the variation in their main indicators of entrepreneurial activity.

The results obtained indicate a high accuracy of the constructed canonical model, since only $6,0 \%(100 \%-94,0 \%)$ of the variance of the Y1-Y3 variables depend on other factors not taken into account in the analysis of the factors.

We obtained three roots with the canonical value of the correlation coefficient $\mathrm{R}=0.994$. This coefficient is significant (because $\mathrm{p}<0.001$ ) and shows the closeness between the canonical variables in the first and second sets. These roots describe $100 \%$ variance of business performance indicators set and $69.4 \%$ variance of the determinants set. These results indicate a fairly strong relationship between the variables of the two sets.

The significance of canonical roots is checked using a criterion (Fig. 5).

\begin{tabular}{|c|c|c|c|c|c|c|}
\hline \multirow[b]{2}{*}{$\begin{array}{l}\text { Root } \\
\text { Removed }\end{array}$} & \multicolumn{6}{|c|}{ Chi-Square Tests with Successive Roots Removed (all countries) } \\
\hline & $\begin{array}{c}\text { Canonicl } \\
\mathrm{R}\end{array}$ & $\begin{array}{c}\text { Canonicl } \\
\text { R-sgr. }\end{array}$ & Chi-sqr. & df & $\mathrm{p}$ & $\begin{array}{l}\text { Lambda } \\
\text { Prime }\end{array}$ \\
\hline 0 & 0,993712 & 0,987464 & 359,1996 & 45 & 0,000000 & 0,000706 \\
\hline 1 & 0,919520 & 0,845516 & 142,4334 & 28 & 0,000000 & 0,056278 \\
\hline 2 & 0,797308 & 0,635700 & 49,9840 & 13 & 0,000003 & 0,364300 \\
\hline
\end{tabular}

Fig. 5. Significance of canonical roots (Chi-Square Tests)

Source: calculations depicted in Statistica 12.

The value of the correlation coefficient $\mathrm{R}=0.994$ for the first canonical root is greater than the value for the second and third canonical roots (Fig. 5). Given that $\mathrm{p}$ $<0.001$ for all correlation coefficients, the three roots are significant. However, further consistent application of the criterion gives grounds to consider only the first canonical root with $\mathrm{R}=0.994$.

Describe the correlations between the variables of each sets, considering their factor structures. The factor structure of the left set showed (Fig. 6) that the variables of the left set strongly correlate with the first canonical factor (0.994). Similarly, the factor structure of the right set (Fig. 7) allows us to identify factors that are greater in loads relative to the first canonical root. These are $\mathrm{X} 1, \mathrm{X} 2, \mathrm{X} 3, \mathrm{X} 4, \mathrm{X} 6, \mathrm{X} 8, \mathrm{X} 12$, $\mathrm{X} 13, \mathrm{X} 15$.

It can be concluded that the significant correlation between variables in the two sets (based on the value of the first root) is most likely due to the relationship between business performance and X1, X2, X3, X4, X6, X8, X12, X13, X15. 
Agricultural and Resource Economics: International Scientific E-Journal http://are-journal.com

\begin{tabular}{|l|c|c|c|}
\hline \hline \multirow{2}{*}{ Variable } & \multicolumn{3}{|c|}{ Factor Structure, left set (all countries) } \\
\cline { 2 - 4 } & Root 1 & Root 2 & Root 3 \\
\hline Y1 & 0,993754 & $-0,071651$ & 0,085553 \\
\hline Y2 & 0,305546 & $-0,946787$ & $-0,101177$ \\
\hline Y3 & 0,988290 & $-0,065532$ & $-0,137797$ \\
\hline
\end{tabular}

Fig. 6. Factor Structure, left set

\begin{tabular}{|l|r|r|r|}
\hline \multirow{2}{*}{$\begin{array}{l}\text { Root } \\
\text { Variable }\end{array}$} & \multicolumn{3}{|c|}{ Factor Structure, right set (all countries) } \\
\cline { 2 - 4 } & \multicolumn{1}{|c|}{ Root 1 } & \multicolumn{1}{|c|}{ Root 2 } & \multicolumn{1}{|c|}{ Root 3 } \\
\hline X1 & 0,670495 & $-0,328802$ & $-0,319499$ \\
\hline X2 & 0,957987 & $-0,230488$ & $-0,078745$ \\
\hline X3 & 0,921638 & $-0,305040$ & 0,136063 \\
\hline X4 & 0,918941 & $-0,320986$ & 0,135444 \\
\hline X5 & 0,359304 & 0,197285 & $-0,266823$ \\
\hline X6 & 0,719798 & $-0,624988$ & $-0,015035$ \\
\hline X7 & 0,486925 & $-0,634504$ & 0,062889 \\
\hline X8 & 0,961082 & $-0,190435$ & $-0,096930$ \\
\hline X9 & $-0,375254$ & $-0,674729$ & 0,091032 \\
\hline X10 & $-0,476773$ & $-0,590555$ & 0,084701 \\
\hline X11 & 0,599997 & 0,263272 & 0,078600 \\
\hline X12 & 0,710119 & $-0,639304$ & 0,003938 \\
\hline X13 & 0,607045 & $-0,355622$ & $-0,308493$ \\
\hline X14 & $-0,118841$ & $-0,137252$ & 0,033922 \\
\hline X15 & 0,874869 & $-0,397638$ & $-0,066425$ \\
\hline
\end{tabular}

Source: calculations depicted in Statistica 12.

Based on the canonical scales of the left (Fig. 8) and right (Fig. 9) sets, respectively, we construct the equations of the canonical models for the variables and for the first canonical root $(\mathrm{R}=0.994)$ :

\begin{tabular}{|l|r|r|r|}
\hline \multirow{2}{*}{ Variable } & \multicolumn{4}{|c|}{ Canonical Weights, left set (all countries) } \\
\cline { 2 - 4 } & \multicolumn{1}{|c|}{ Root 1 } & \multicolumn{1}{c|}{ Root 2 } & \multicolumn{1}{c|}{ Root 3 } \\
\hline Y1 & 0,602461 & $-0,28163$ & 4,45482 \\
\hline Y2 & $-0,075310$ & $-1,07755$ & $-0,02768$ \\
\hline Y3 & 0,429340 & 0,61633 & $-4,47089$ \\
\hline
\end{tabular}

Fig. 8. Canonical Weights, left set

\begin{tabular}{|l|r|r|r|}
\hline \multirow{2}{*}{ Variable } & \multicolumn{3}{|c|}{ Canonical Weights, right set (all countries) } \\
\cline { 2 - 4 } & Root 1 & Root 2 & \multicolumn{1}{|c|}{ Root 3} \\
\hline X1 & $-0,02070$ & $-0,1801$ & $-0,57985$ \\
\hline X2 & 1,23597 & $-0,4955$ & 1,63885 \\
\hline X3 & 1,33229 & 2,6856 & $-1,94907$ \\
\hline X4 & $-1,08345$ & $-1,0770$ & 4,60753 \\
\hline X5 & 0,02778 & 0,0589 & $-0,09351$ \\
\hline X6 & 1,05328 & 22,6889 & 5,82566 \\
\hline X7 & 0,33380 & 2,0359 & $-0,41238$ \\
\hline X8 & $-0,07339$ & $-1,0714$ & $-5,18632$ \\
\hline X9 & $-0,01965$ & $-0,0210$ & $-1,71967$ \\
\hline X10 & 0,07923 & $-0,2778$ & 1,26004 \\
\hline X11 & 0,10413 & 0,0784 & 0,66231 \\
\hline X12 & $-1,87061$ & $-26,6735$ & $-4,52424$ \\
\hline X13 & $-0,18266$ & $-0,1910$ & $-0,77048$ \\
\hline X14 & 0,00875 & 0,0295 & $-0,09368$ \\
\hline X15 & 0,16648 & 1,9080 & 0,72474 \\
\hline
\end{tabular}

Fig. 9. Canonical Weights, right set

$$
\begin{gathered}
U=0,602461 Y_{1}-0,075310 Y_{2}+0,429340 Y_{3}, \\
V=-0,02070 X_{1}+1,23597 X_{2}+1,33229 X_{3}-1,08345 X_{4}+0,02778 X_{5}+ \\
+1,05328 X_{6}+0,33380 X_{7}-0,07339 X_{8}-0,01965 X_{9}+0,07923 X_{10}+ \\
+0,10413 X_{11}-1,87061 X_{12}-1,18266 X_{13}+0,00875 X_{14}+0,16648 X_{15} .
\end{gathered}
$$

Analysis of the value of the correlation coefficient for the first canonical root, suggests the existence of a fairly close relationship between the linear combinations of source variables, i.e. business efficiency indicators are closely related to the 
studied determinants.

The canonical correlation method allows to associate a set of factor indicators not with one performance measure, but with several, which increases the objectivity of analytical conclusions as a basis for management decisions.

The relationship between the values of the canonical variables from the right and left sets is shown in Fig. 10.

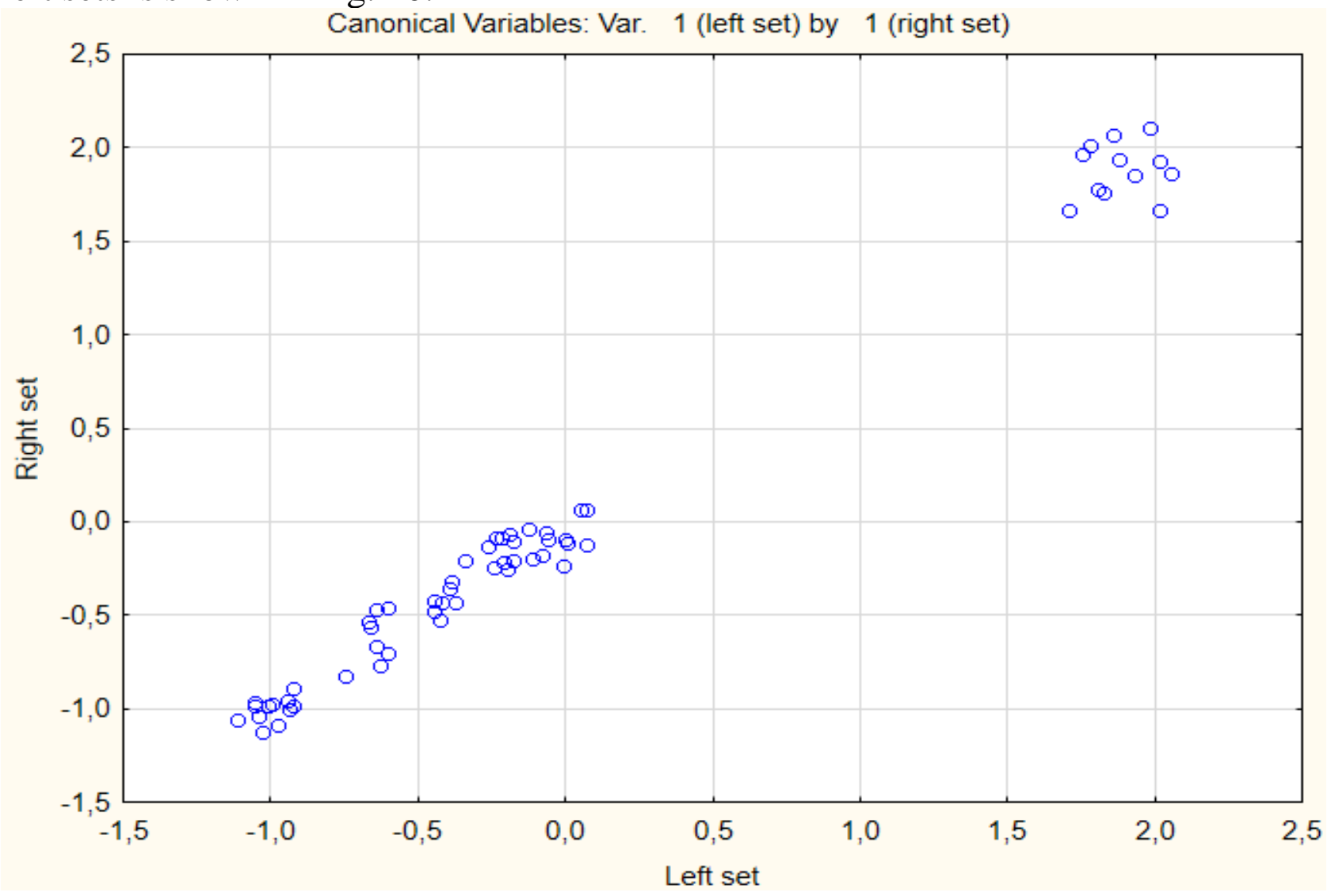

Fig. 10. Scatterplot of canonical correlations for the first canonical root

Source: calculations depicted in Statistica 12.

Fig. 10 shows that there are no pronounced deviations from the regression model. Thus, we can conclude that the basic assumptions of canonical analysis are confirmed. However, the graph clearly shows the division of observational data into two groups. The reason for this is the heterogeneity of the studied data sample, i.e. the large difference between the numerical values of the indicators for the selected countries. In the case of a uniform distribution of data on the graph, it could be argued that the nature of such relationships between the selected sets of variables is the same for all selected countries.

Therefore, it is worth analyzing these relationships between selected performance indicators and selected determinants separately for each country.

Correlations within and between sets make it possible to analyze the correlation matrices that characterize the relationship between variables. The matrix of the relationship between performance variables (Y) and factors (X) (Table 3) for countryby-country data is presented. 
Agricultural and Resource Economics: International Scientific E-Journal http://are-journal.com

Table 3

Correlations within and between sets

\begin{tabular}{|c|c|c|c|}
\hline Factors & Y1 & Y2 & Y3 \\
\hline $\mathrm{X} 1$ & 0,661986 & 0,364980 & 0,713392 \\
\hline $\mathrm{X} 2$ & 0,955832 & 0,471383 & 0,963357 \\
\hline X3 & 0,939501 & 0,544616 & 0,908550 \\
\hline $\mathrm{X} 4$ & 0,937846 & 0,552430 & 0,906931 \\
\hline $\mathrm{X} 5$ & 0,323615 & $-0,059344$ & 0,370290 \\
\hline X6 & 0,750955 & 0,836580 & 0,746208 \\
\hline $\mathrm{X7}$ & 0,526935 & 0,824186 & 0,509522 \\
\hline $\mathrm{X} 8$ & 0,955009 & 0,449379 & 0,965980 \\
\hline $\mathrm{X} 9$ & $-0,319901$ & 0,684252 & $-0,337871$ \\
\hline $\mathrm{X} 10$ & $-0,426129$ & 0,598486 & $-0,441947$ \\
\hline X11 & 0,580516 & $-0,145035$ & 0,564742 \\
\hline $\mathrm{X} 12$ & 0,743635 & 0,844015 & 0,735481 \\
\hline $\mathrm{X} 13$ & 0,601848 & 0,401525 & 0,651487 \\
\hline X14 & $-0,106000$ & 0,264319 & $-0,112168$ \\
\hline $\mathrm{X} 15$ & 0,885605 & 0,634947 & 0,890446 \\
\hline
\end{tabular}

Note. Marked correlations are significant at $\mathrm{p}<, 05000 . \mathrm{N}=60$ (Casewise deletion of missing data).

Source: own calculations.

An analysis of the matrix data showed that the traits $\mathrm{Y} 1-\mathrm{Y} 3$ are quite closely related to $\mathrm{X} 1-\mathrm{X} 4, \mathrm{X} 6, \mathrm{X} 8, \mathrm{X} 12, \mathrm{X} 15$ (defined simultaneously by three correlation coefficients) and are less closely related to the variables X7, X13, X5, X11.

The rank order of factors affecting the main criteria of entrepreneurial activity is as follows: imports (X4), exports (X3), enterprise personnel costs (X15), share capital per person (X2), average wages (X8), number of employed population (X6), economically active population (X12), total innovation expenditures in the economy (X1), number of unemployed population (X7), employers' need for workers (X13), income per person (X11), capital investment (X5)), dynamics of real disposable income (X14), sales volume of enterprises (X9), household income (X10).

That is, first of all, entrepreneurship is determined by the openness of the national economy, investment in the development of share capital and innovation (X15 and X2) and a considerable degree of utilization of labor potential. Would-be entrepreneurs' financial conditions have been found to be an important determinant for their entrepreneurial activities (Holtz-Eakin et al., 1994; Hurst and Lusardi, 2004). These tenets of scholars can be confirmed by the close relationship with the determinants (X8, X11, X14, and X10).

Thus, the financial standard of living of the population is very important as it is a potential entrepreneurial environment. After all, business needs investment and external financing is limited by formal barriers.

The weak correlation of the factors can be explained by the volatility of fluctuations in economic systems such as capital investment. A weak link is also 
observed with the dynamics of real disposable income of the population (X14) and the volume of products sold by enterprises (X9), income of the population (X10), which testifies to the relative independence of the results of entrepreneurial activity from the standard of living of the population.

The results of the canonical analysis confirmed that the relationships between the selected performance indicators and the selected determinants should be investigated for each country separately. The study of the relationships for data from other countries can serve as the beginning of building a favorable business environment system for Ukraine.

On the basis of correlation coefficients, the influence of various factors on the main indicators of business activity for the selected countries is analyzed and formed (Appendix A).

Empirical evaluation of the results of correlation analysis.

1. There is a strong correlation between innovation expenditures and GDP per capita in Poland, Lithuania and Romania. This situation can be explained by the fact that innovation is a vector of EU development and the share of such costs is one of the conditions for EU membership. In Poland and Lithuania, this indicator is also related to the output, which testifies to the convenient conditions for the introduction of innovations into production and the protection of capital.

Thus, Germany is highly innovative and its modern innovative structure belongs to Industry 4.0, but innovation is determined by the resultant German entrepreneurial performance on a number of other factors, which will be identified in many indicators.

2. The share capital ratio correlates with the output in Poland, which is caused by the protection of property relations and the stability of the economic situation, which is the main requirement for investing in capital.

Share capital determines the GDP per capita in Lithuania and Romania, which is linked to the favorable economic situation and the development of exchange relations.

In Ukraine, this indicator has a negative impact on the Global Competitiveness Index. The reasons are the underdeveloped stock market in the country and its institutional support.

3. In Ukraine, Poland, Lithuania and Romania, exports determine such indicators as GDP per capita and output, which shows, on the one hand, the openness of the economy and, on the other, the dependence of the national market on external conditions. Exports determine the competitive position in the Global Competitiveness Index of EU Member States, in our sample of Lithuania, Poland and Romania.

In Germany there is a specific situation regarding the determinants of exports, since, unlike other countries surveyed, exports do not have a significant impact on any resultant indicator. This situation is largely due to the predominance of exports of finished goods in Germany, which allows to balance the influence of various determinants on entrepreneurial activity and not depend on several ones.

4. Import-oriented GDP per capita and output in Ukraine and Poland. GDP per 


\section{Agricultural and Resource Economics: International Scientific E-Journal}

http://are-journal.com

capita correlates with imports in Lithuania and Romania. Such interdependence testifies to the openness of the market, on the one hand, and to the potential of the internal market, on the other.

For example, one can consider the situation in Germany, where the correlation is insignificant, indicating that domestic capacity is being used to meet domestic demand in general, which is positively reflected in the foreign trade balance.

5. Capital investment is closely linked to GDP per capita in Poland. Factors: prospects for the development of the country as a whole; availability of institutional support for investment in the country.

6 . The correlation between the number of employed population and the level of GDP per capita and the volume of products produced is observed in Poland, in which a large share of public expenditure is directed towards regulating the labor market and creating conditions for labor mobilization in the country.

7. In Lithuania and Romania, the number of unemployed people has a negative impact on GDP per capita, linked to social protection programs.

It should be noted that Germany is one of the countries with the highest employment rate in the EU and has the lowest percentage of unemployed youth, which confirms the correct choice of the national economy standard among the countries studied.

8. The average wage is a determinant of GDP per capita and output in all the countries studied except Germany. This country was able to balance the impact of this determinant on the results of entrepreneurial activity.

The average wage rate largely determines the competitive position of Poland, Lithuania and Romania.

9. The resultant indicator of entrepreneurial activity - the volume of sales of products (goods, services) by enterprises - is closely correlated with GDP per capita and output. This connection seems natural and straightforward. But there is no such link in Germany, which once again confirms the balance of the factors affecting all the performance indicators of a country known for GDP surplus.

10. Population income as a determinant of market opportunity potential is closely linked to GDP per capita and output of Ukraine, Lithuania and Romania.

Finally, we find the determinant of Germany's competitive position - population income, which is also characteristic of Romania and Lithuania.

11. The per capita disposable income largely determines GDP per capita and positions in the Global Competitiveness Index of Lithuania and Romania.

12. The index of economically active population influences the positions in the Global Index in Germany. There is no other link in the other countries studied. This connection is explained by the fact that the model of social market economy is the basis of German economic policy.

13. Employers' need for workers correlates with output in Poland. This connection is explained by Poland's emphasis on the dynamic development of the labor market.

14. Dynamics of real disposable income correlates with the Competitiveness 


\section{Agricultural and Resource Economics: International Scientific E-Journal http://are-journal.com}

Index in only one of the most socially oriented countries - Germany, which is selected as the highest performing model.

15. In Poland, all three performance indicators are closely linked to the cost of staff, confirming, at the same time, that new social payments and tax cuts are contributing to economic growth.

The human development of entrepreneurial activity is characterized by an indicator of personnel costs, which has a significant impact on GDP per capita in Ukraine, which indicates the dependence of GDP on labor resources in the country to a large extent.

Therefore, the advantage of the proposed methodical approach is that the methodology is based on a comprehensive, multilateral approach to the assessment of all components of the determinants of entrepreneurial activity.

The disadvantage of this technique is the neglect of factors that did not appear in the reporting indicators.

Empirical evaluation of correlation coefficients to assess the impact of various factors on the main indicators of business activity of the studied countries allowed to explain the difference between such relationships in different countries. Based on this study, there were attempts to analyze the reasons for the dynamics of change in these indicators and factors.

For Ukraine, such an approach should ensure real socio-economic transformations, in which the positive dynamics of business development is key.

Therefore, from the analysis of the canonical interrelation of the performance indicators of business activity and the totality of indicators, we see that the hypotheses have been confirmed.

It follows from the above that modeling of the processes of the new entrepreneurship development requires a large amount of data in the regional dimension, which characterizes all sides of this process. In this case, certain tools should be selected to reduce the sets of input variables while establishing an analytic view of the relationship between these sets. The method of canonical correlation (Figs. 8, 9) allows to reduce the number of factors due to the elimination of lowinfluence factors.

Conclusions. The efficiency of economic growth depends on the harmonized interaction of the whole system of determinants of business activity (as an example, Germany). Thus, the analysis showed no significant impact on GDP per capita and output of all factor indicators.

Therefore, it can be argued that the key to the success of entrepreneurial activity is the harmonious development of all determinants of entrepreneurial activity to such an extent that no indicator determines the level of development of the national economy to a great extent. In this way, economic self-sufficiency is ensured.

The basis of modern economic policy of development of the national economy of the countries which occupy high results and rates of development are sociallyoriented determinants. Thus, the human development determinants that the determine of business affect the economic performance of entrepreneurship, determine the 


\section{Agricultural and Resource Economics: International Scientific E-Journal}

http://are-journal.com

position of the national economy in international indices and in an integrated market environment.

Further research should address the prediction and modeling of entrepreneurial performance, depending on the change in individual determinants and the quantitative change in individual indicators.

This study showed what determinants of entrepreneurial activity could explain the development of entrepreneurial activity in these countries. However, due to the limitations of the data, this study could not fully account in particular for the institutional, educational, welfare components for each country. This is left as a task for future research.

\section{References}

1. Prieger, J. E., Bampoky, C., Blanco, L. R. and Liu, A. (2016), Economic growth and the optimal level of entrepreneurship. World Development, vol. 82, pp. 95-109. https://doi.org/10.1016/j.worlddev.2016.01.013.

2. Urbano, D. and Aparicio, S. (2016), Entrepreneurship capital types and economic growth: international evidence. Technological Forecasting and Social Change, vol. 102, pp. 34-44. https://doi.org/10.1016/j.techfore.2015.02.018.

3. García-Villaverde, P. M., Rodrigo-Alarcón, J., Parra-Requena, G. and RuizOrtega, M. J. (2018), Technological dynamism and entrepreneurial orientation: the heterogeneous effects of social capital. Journal of Business Research, vol. 83, pp. 5164. https://doi.org/10.1016/j.jbusres.2017.10.004.

4. Aparicio, S., Urbano, D. and Audretsch, D. (2016), Institutional factors, opportunity entrepreneurship and economic growth: panel data evidence. Technological Forecasting and Social Change, vol.102, pp.45-61. https://doi.org/10.1016/j.techfore.2015.04.006.

5. Fuentelsaz, L., Gonzales, C. and Maícas, J. P. (2015), How different formal institutions affect opportunity and necessity entrepreneurship. BRQ Business Research Quarterly, vol. 18, is. 4, 246-258. https://doi.org/10.1016/j.brq.2015.02.001.

6. Boudreaux, C. J., Nikolaev, B. N. and Klein, P. (2019), Socio-cognitive traits and entrepreneurship: the moderating role of economic institutions. Journal of Business Venturing, vol. 34, is. 1, pp. 178-196. https://doi.org/10.1016/j.jbusvent.2018.08.003.

7. Dvouletý, O. (2018), How to analyse determinants of entrepreneurship and selfemployment at the country level? A methodological contribution. Journal of Business Venturing Insights, vol. 9, pp. 92-99. https://doi.org/10.1016/j.jbvi.2018.03.002.

8. Jiangyong, L. and Zhigang, T. (2010), Determinants of entrepreneurial activities in China. Journal of Business Venturing, vol. 25, is. 3, pp. 261-273. https://doi.org/10.1016/j.jbusvent.2008.10.005.

9. Hotelling, H. (1936), Relations between two sets of variates. Biometrika, vol. 28, no. 3/4, pp. 321-377. https://doi.org/10.2307/2333955.

10. Volchek, R. (2012), Canonical correlations as an analytical tool for 
managing the financial condition of food industry enterprises. Ekonomika APK, no. 11 , pp. 69-78.

11. Marcotte, C. (2013), Measuring entrepreneurship at the country level: a review and research agenda. Entrepreneurship and Regional Development, vol. 25, is. 3-4, pp. 174-194. https://doi.org/10.1080/08985626.2012.710264.

12. Acs, Z., Autio, E. and Szerb, L. (2014), National systems of entrepreneurship: measurement issues and policy implications. Research Policy, vol. 43, is. 3, pp. 476-494. https://doi.org/10.1016/j.respol.2013.08.016.

13. Iversen, J., Jørgensen, R. and Malchow-Moeller, N. (2010), Defining and measuring entrepreneurship. Foundations and Trends in Entrepreneurship, vol. 4, is. 1, pp. 1-63. https://doi.org/10.1561/0300000020.

14. Congregado, E., Golpe, A. A., Millan, J. M. and Román, C. (2008), Building a statistical system on entrepreneurship: a theoretical framework In Measuring Entrepreneurship. International Studies in Entrepreneurship, vol. 16. Springer, Boston, MA., USA. https://doi.org/10.1007/978-0-387-72288-7_16.

15. Eurostat, (2018), available at: http://ec.europa.eu/eurostat/data/database.

16. Global Innovation Index (2019), available at: https://www.wipo.int/edocs/pubdocs/en/wipo_pub_gii_2019.pdf.

17. Index of Economic Freedom (2019), available at: https://www.heritage.org/index.

18. Ease of doing business Index (2019), available at: https://www.doingbusiness.org/content/dam/doingBusiness/media/AnnualReports/English/DB2019-report_web-version.pdf.

19. Human Development Index (2019), available at: http://hdr.undp.org/en/data.

20. Global Competitiveness Report (2018), available at: http://www3.weforum.org/docs/GCR20172018/05FullReportTheGlobalCompetitiven essReport2017\%E2\%80\%932018.pdf.

21. Holtz-Eakin, D., Joulfaian, D. and Rosen, H. (1994), Entrepreneurial decisions and liquidity constraints. Rand Journal of Economics, vol. 25, is. 2, pp. 334-347. https://doi.org/10.2307/2555834.

22. Hurst, E. and Lusardi, A. (2004), Liquidity constraints, household wealth, and entrepreneurship. Journal of Political Economy, vol. 112, no. 2, pp. 319-347. https://doi.org/10.1086/381478. 


\section{Appendix}

Table A.1

The influence of various factors on the main indicators of business activity for the selected countries

\begin{tabular}{|c|c|c|c|c|c|c|c|c|c|c|c|c|c|c|c|}
\hline & \multicolumn{3}{|c|}{ Ukraine } & \multicolumn{3}{c|}{ Romania } & \multicolumn{3}{c|}{ Lithuania } & \multicolumn{3}{c|}{ Poland } & \multicolumn{3}{c|}{ Germany } \\
\hline & Y1 & Y2 & Y3 & Y1 & Y2 & Y3 & Y1 & Y2 & Y3 & Y1 & Y2 & Y3 & Y1 & Y2 & Y3 \\
\hline X1 & 0,294 & 0,065 & $-0,332$ & 0,648 & 0,441 & 0,374 & 0,653 & 0,331 & 0,190 & 0,943 & 0,911 & 0,902 & $-0,161$ & 0,172 & 0,136 \\
\hline X2 & $-0,022$ & $-0,027$ & $-0,532$ & 0,784 & 0,526 & 0,697 & $-0,452$ & $-0,579$ & $-0,712$ & 0,675 & 0,871 & 0,541 & $-0,318$ & 0,087 & 0,473 \\
\hline X3 & 0,914 & 0,868 & $-0,358$ & 0,900 & 0,658 & 0,786 & 0,731 & 0,563 & 0,531 & 0,775 & 0,822 & 0,845 & 0,626 & $-0,117$ & $-0,342$ \\
\hline X4 & 0,942 & 0,880 & $-0,315$ & 0,958 & 0,660 & 0,723 & 0,781 & 0,508 & 0,591 & 0,900 & 0,919 & 0,833 & 0,663 & $-0,078$ & $-0,391$ \\
\hline X5 & $-0,003$ & $-0,059$ & $-0,049$ & 0,423 & 0,355 & 0,680 & 0,111 & 0,551 & 0,633 & 0,832 & 0,766 & 0,846 & $-0,485$ & 0,259 & 0,606 \\
\hline X6 & 0,494 & 0,547 & $-0,461$ & $-0,035$ & $-0,133$ & $-0,156$ & $-0,120$ & 0,021 & 0,531 & 0,845 & 0,865 & 0,597 & $-0,611$ & 0,208 & 0,858 \\
\hline X7 & $-0,391$ & $-0,247$ & 0,258 & $-0,869$ & $-0,624$ & $-0,622$ & $-0,176$ & $-0,212$ & $-0,681$ & $-0,737$ & $-0,695$ & $-0,365$ & 0,236 & $-0,085$ & $-0,588$ \\
\hline X8 & 0,873 & 0,849 & $-0,108$ & 0,931 & 0,803 & 0,834 & 0,284 & 0,816 & 0,731 & 0,853 & 0,851 & 0,902 & $-0,351$ & 0,090 & 0,672 \\
\hline X9 & 0,722 & 0,766 & $-0,473$ & 0,878 & 0,823 & 0,656 & 0,426 & 0,716 & 0,497 & 0,782 & 0,839 & 0,921 & $-0,153$ & 0,061 & 0,458 \\
\hline X10 & 0,753 & 0,869 & $-0,263$ & 0,902 & 0,776 & 0,748 & 0,478 & 0,791 & 0,624 & 0,102 & 0,185 & $-0,084$ & $-0,400$ & 0,120 & 0,831 \\
\hline X11 & 0,220 & 0,078 & $-0,273$ & 0,842 & 0,590 & 0,776 & 0,491 & 0,791 & 0,627 & 0,641 & 0,689 & 0,509 & $-0,470$ & 0,219 & 0,735 \\
\hline X12 & 0,435 & 0,515 & $-0,460$ & $-0,501$ & $-0,486$ & $-0,592$ & $-0,739$ & $-0,515$ & $-0,428$ & 0,766 & 0,692 & 0,661 & $-0,607$ & 0,250 & 0,922 \\
\hline X13 & $-0,003$ & 0,014 & $-0,237$ & $-0,647$ & $-0,633$ & $-0,718$ & 0,497 & 0,230 & 0,512 & 0,534 & 0,815 & 0,570 & 0,283 & $-0,026$ & $-0,056$ \\
\hline X14 & 0,495 & 0,504 & 0,046 & 0,658 & 0,634 & 0,297 & $-0,610$ & 0,220 & $-0,082$ & 0,546 & 0,157 & 0,355 & 0,004 & $-0,409$ & $-0,693$ \\
\hline X15 & 0,752 & 0,864 & $-0,325$ & 0,013 & 0,080 & 0,154 & 0,459 & 0,730 & 0,486 & 0,877 & 0,897 & 0,878 & $-0,420$ & $-0,012$ & 0,577 \\
\hline
\end{tabular}

Note. Marked correlations are significant at $\mathrm{p}<, 05000$.

Source: data from Eurostat (2019); Global Innovation Index (2019); Human Development Index (2019) Global Competitiveness Report (2019) database adapted to the mathematical model.

Citation:

Стиль-ДСТУ:

Kyfyak V., Vinnychuk O., Sybyrka L., Vodianka L. Measuring entrepreneurship determinants: empirical analysis. Agricultural and Resource Economics. 2021. Vol. 7. No. 2. Pp. 40-58. https://doi.org/10.51599/are.2021.07.02.03.

Style-APA:

Kyfyak, V., Vinnychuk, O., Sybyrka, L. and Vodianka, L. (2021), Measuring entrepreneurship determinants: empirical analysis. Agricultural and Resource Economics, vol. 7, no. 2, pp. 40-58. https://doi.org/10.51599/are.2021.07.02.03. 